\title{
Relying on Skills Competition to Improve the Quality of Skilled Talents Training in Vocational Schools
}

\author{
Xu Yishe ${ }^{1, a}$, Liu Chunyan, ${ }^{1, b}$, Zhou Hongbo ${ }^{2, c}$ \\ ${ }^{1}$ Hunan Mechanical \& Electronical Polytechnic, Changsha, Hunan 410151, China \\ ${ }^{2}$ Hunan Provincial Research Institute of Education, Changsha, Hunan 410001, China \\ a763438598@qq.com, b458697871@qq.com, '382245616@qq.com
}

Keywords: Skills competition; Vocational schools; Skilled talents; Training quality

\begin{abstract}
In recent years, the Polytechnic has continuously participated in or undertaken the competition items of installation and debugging of automated production lines, application of industrial robot technology, and installation and debugging of electrical control systems in provincial and state-level vocational students' skills competitions. Based on the analysis of the contents, technical requirements and skill standards of the three competitions, the Polytechnic provides training of comprehensive skills to its students, including professional knowledge, practical skills and professional quality, presenting how vocational schools can improve the quality of talents training in response to the requirements skill competitions.
\end{abstract}

\section{Introduction}

The National Vocational Students Skills Competition has become a high-level competition among vocational schools. With its extended cooperation with industries and enterprises, it has gained support from governments at all levels and recognition of all walks of life. The Competition advocates the training of skills aiming at meeting the requirements of companies on employees, and Hunan Province pays special attention to the training of high-quality "Furong Craftsmen"1 who fill the needs of the industrial transformation and upgrading of the province.

Hunan Mechanical \& Electronical Polytechnic (hereinafter referred to as "the Polytechnic") takes professional skills competitions as significant initiatives in the training and selection of high-quality skilled talents. It has continuously participated in or hosted school-level, provincial-level and national-level professional skills competitions. As one of the venues of the Hunan Provincial Vocational Students Skills Competition, the Polytechnic has organized 16 events in 6 Competitions ever since the first provincial competition. To date, it has participated in 82 competitions items in the Hunan Provincial Vocational Students Skills Competitions, and has been awarded 11 first prizes, 38 second prizes and 44 third prizes. It has participated in 26 competition items in the National Vocational Students Skills Competitions, and has been awarded 1 first prize, 7 second prizes, and 13 third prizes. With its participation in both the provincial and national vocational school student skills competitions, the Polytechnic set its goal of training for provincial-level skilled talents, at the same time, it learnt and summarized the standards for the training of national-level skilled talents. And from the hosting of provincial-level vocational student skills competitions, it has gained rich experience in skilled talents training. A new pattern of "learning through competition" and "training with competition" has been in shape for the training of skilled talents in the Polytechnic.

With the rapid development and mutual penetration of computer technology, communication technology, automatic control technology, bus technology, signal detection technology and microelectronics technology, intelligent control technology has made great progress, and developing a specialty category for the training of intelligent control talents has become the key teaching project of the Polytechnic. The specialty category of intelligent control technology mainly covers mechatronics technology, industrial robotics, and electrical automation, and they correspond

\footnotetext{
"Furong" is the Chinese Pinyin of hibiscus, the floral emblem of Hunan Province.
} 
respectively to the three competition items of installation and debugging of automated production lines, application of industrial robot technology, and installation and debugging of electrical control systems under the equipment manufacturing competition category of the National Vocational Students Skills Competition, which are also the three regular competition items of the Hunan Provincial Vocational Students Skills Competitions that the Polytechnic has hosted. With comprehensive analysis on the characteristics of the above three competition items (as shown in Tables 12 and 3), the awards the Polytechnic has gained (as shown in Table 4), and the objectives and standards of talents training learnt from the competitions, the quality of vocational talents training in the Polytechnic can be further enhanced.

Based on analysis of the characteristics of these three competition items in terms of content, technical specifications, and mission requirements ever since the starting year, the equipment for the installation and debugging of automated production lines is a typical refinement of the actual production line at the industrial site, and is a high-simulation flexible automatic production line. The competition of the application of industrial robot technology takes the industrial robot workstation as the platform, highlighting the design, installation, programming, debugging and maintenance of the industrial robot workstation system. The equipment of the competition of the installation and debugging of the electric control system is a typical equipment based on the real electrical control system at the industrial site, highlighting the installation, debugging and configuration of a typical electrical control system. The content and the application of technologies of the three competitions accords with the core competence requirements of the automation specialties category specified in the Instructional Specialty Catalogue for Higher Vocational Education (Trial) issued by the Ministry of Education, is in line with the training targets for electricity specialties of higher vocational education stated in the specialty guidance catalogue issued by the Ministry of Education. These competitions integrate various professional core knowledge and technical skills into the production line, emphasize the comprehensive application of technologies, and highlight the abilities of teamwork, planning, organization, and communication of higher vocational students.

Table 1 Introduction to Installation and Debugging of Automated Production Lines

\begin{tabular}{|c|c|c|c|c|}
\hline Item & Year & Content & Technical Specifications & Task \\
\hline 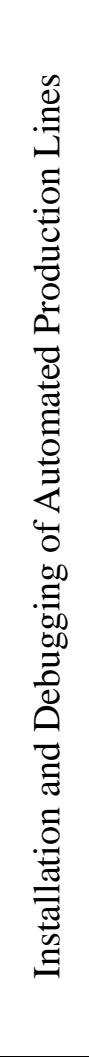 & $\begin{array}{l}2012 \\
2013 \\
2015\end{array}$ & $\begin{array}{l}\text { Mechanical } \\
\text { installation and } \\
\text { adjustment of some } \\
\text { of the workstations } \\
\text { (feeding station, } \\
\text { conveying station, } \\
\text { processing station, } \\
\text { assembly station } \\
\text { and sorting station) } \\
\text { of the automatic } \\
\text { production line } \\
\text { equipment; } \\
\text { installation, } \\
\text { connection and } \\
\text { adjustment of } \\
\text { pneumatic circuit; } \\
\text { installation and } \\
\text { wiring of electrical } \\
\text { control circuit; } \\
\text { sensor installation } \\
\text { and adjustment; } \\
\text { PLC programming; } \\
\text { Man-machine } \\
\text { interface }\end{array}$ & $\begin{array}{l}\text { 1.Technologies and skills: sensor technology, pneumatic } \\
\text { technology, low-voltage electrical control technology, } \\
\text { industrial network technology, programmable controller } \\
\text { technology, inverter technology, stepper motor } \\
\text { technology, electrical system installation and debugging } \\
\text { skills, mechanical system installation and debugging } \\
\text { skills, and system maintenance and fault detection skills. } \\
\text { 2.Technical Standards: Electrical equipment of } \\
\text { machine-tools - General requirements (GB_5226-85), } \\
\text { Pneumatic fluid power - General rules relating to } \\
\text { systems (GB/T 7932-2003), Code for construction and } \\
\text { acceptance of switchboard outfit complete cubicle and } \\
\text { secondary circuit electric machines electric equipment } \\
\text { installation engineering (GB 50171-92 ), Quality } \\
\text { inspection provisions for electronic measuring } \\
\text { instruments (GB/T6593-1996), Electric-driving control } \\
\text { gear, Part } 1 \text { Electric-driving control gear composed of } \\
\text { low-voltage apparatus (GB4720), Code for construction } \\
\text { and acceptance of low-voltage apparatus electric } \\
\text { equipment installation engineering (GB50254) } \\
\text { Programmable Controller } \quad \text { (GB/T } \\
\text { 15969-1995),Graphical symbols for use on electrical } \\
\text { diagram of industrial machines (JB/T 2739-2008), } \\
\text { Electrical equipment of industrial machines drawing of }\end{array}$ & $\begin{array}{l}\text { Completes } \\
\text { installing, } \\
\text { programming } \\
\text { and } \\
\text { debugging of } \\
\text { the single } \\
\text { station } \\
\text { production } \\
\text { line within } \\
\text { the stipulated } \\
\text { time; execute } \\
\text { overall } \\
\text { system test to } \\
\text { allow the } \\
\text { production to } \\
\text { complete the } \\
\text { following } \\
\text { tasks on the } \\
\text { assembly } \\
\text { including } \\
\text { discharging } \\
\text { from the } \\
\text { storehouse, } \\
\text { transiting, }\end{array}$ \\
\hline
\end{tabular}




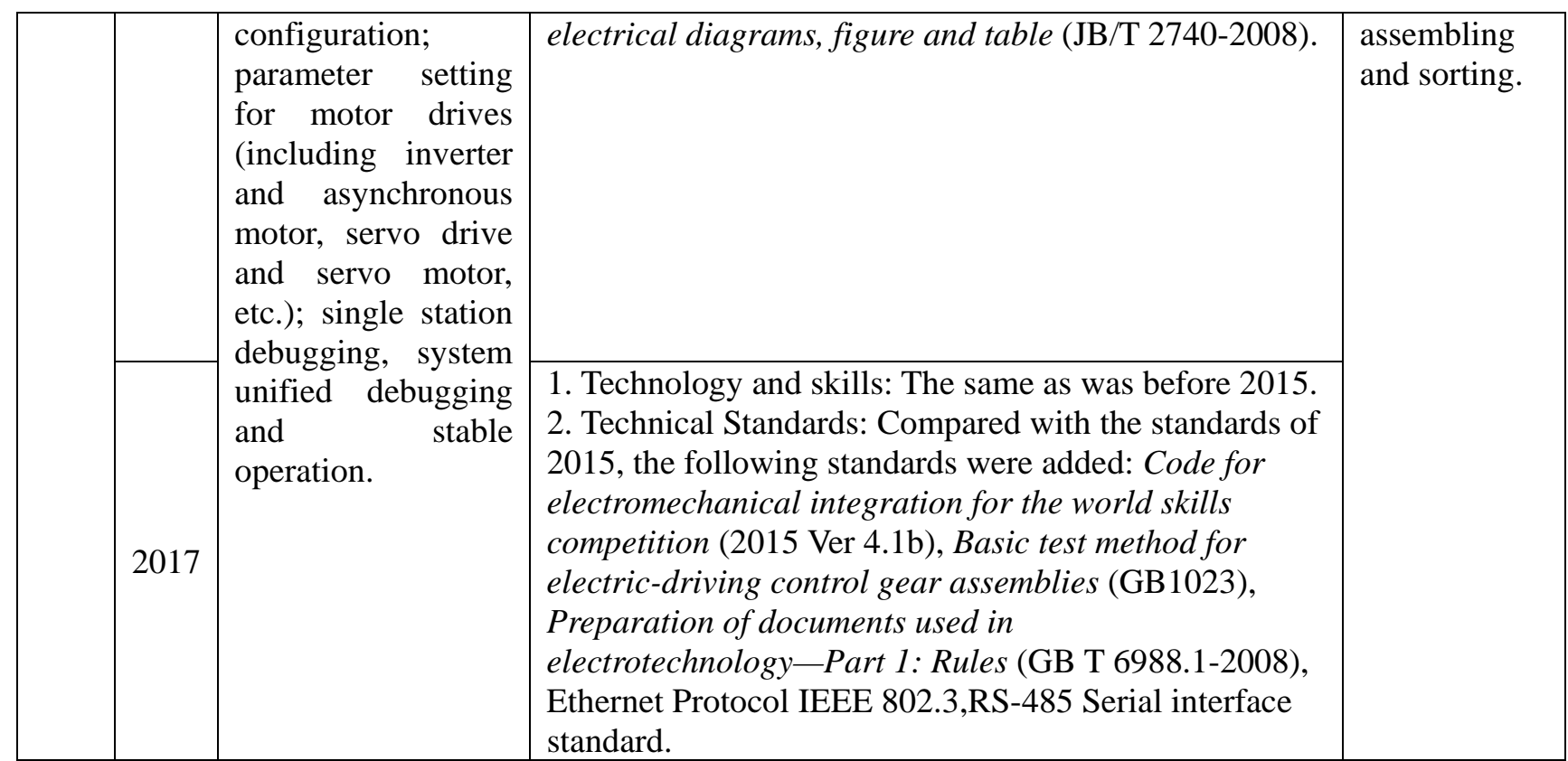

Table 2 Introduction to the Application of Industrial Robot Technology

\begin{tabular}{|c|c|c|c|c|}
\hline Item & Year & Content & Technical Specifications & Task \\
\hline 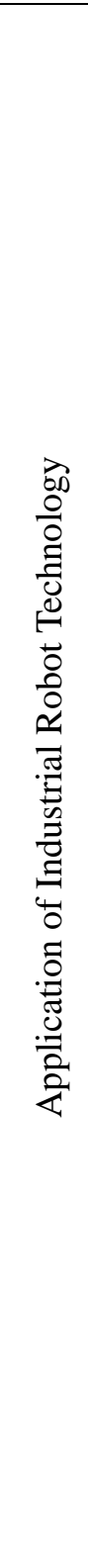 & 2016 & $\begin{array}{l}\text { Mechanical and } \\
\text { electrical installation and } \\
\text { debugging for single } \\
\text { suction and double } \\
\text { suction six-axis } \\
\text { industrial robot } \\
\text { end-effectors; } \\
\text { Mechanical } \\
\text { electrical installation and } \\
\text { debugging for the upper } \\
\text { conveyor line of mobile } \\
\text { robots; process editing } \\
\text { for Intelligent Vision } \\
\text { System, realizing } \\
\text { recognition of the } \\
\text { shape, type, location and } \\
\text { angle of the gift boxes; } \\
\text { parameter setting and } \\
\text { calibration of industrial } \\
\text { robot and establishment } \\
\text { and testing of } \\
\text { communication links } \\
\text { with PLC; basic module } \\
\text { unit test of the } \\
\text { competition platform; } \\
\text { programming for } \\
\text { man-machine interface, } \\
\text { communication and } \\
\text { underlying control } \\
\text { programs, including the } \\
\text { communication } \\
\text { programs for the robot, } \\
\text { the assembly line and the } \\
\text { stacking machine; } \\
\text { complete the overall } \\
\text { system operation, }\end{array}$ & $\begin{array}{l}\text { 1. Technologies and skills: application of } \\
\text { mechanical and electrical technology, pneumatic } \\
\text { control technology, variable frequency speed } \\
\text { regulation, stepper drive system, servo drive } \\
\text { technology, PLC automatic control and } \\
\text { configuration technology, motion control } \\
\text { technology and precision positioning control } \\
\text { technology, visual identification technology, robot } \\
\text { control technology, electrical installation and } \\
\text { debugging technology, mechanical installation and } \\
\text { debugging technology, as well as system } \\
\text { maintenance and fault detection technology. } \\
\text { 2.Occupational standards: National occupational } \\
\text { standards for electrical maintenance (Occupation } \\
\text { Codes 6-07-06-05), National occupational } \\
\text { standards for tool fitters (Occupation Code } \\
\text { 6-05-02-02), National occupational standards for } \\
\text { assembly fitters (Occupation Code 6-05-02-01), } \\
\text { National occupational standards for mechanical } \\
\text { equipment installers (Occupation Code } \\
\text { 6-23-10-01), National occupational standards for } \\
\text { programmable control system designers } \\
\text { (Occupation Code X 2-02-13-10). }\end{array}$ & $\begin{array}{l}\text { Execute } \\
\text { joint } \\
\text { debugging } \\
\text { for the } \\
\text { palletizing } \\
\text { machine, } \\
\text { the AGV, } \\
\text { the pallet } \\
\text { assembly } \\
\text { line, the } \\
\text { vision } \\
\text { system, the } \\
\text { six-axis } \\
\text { industrial } \\
\text { robot to } \\
\text { allow the } \\
\text { assembly } \\
\text { line to } \\
\text { execute the } \\
\text { below tasks } \\
\text { on the } \\
\text { giftbox } \\
\text { including } \\
\text { discharging } \\
\text { from the } \\
\text { storehouse, } \\
\text { transiting, } \\
\text { recognition } \\
\text { and sorting. } \\
\text { - }\end{array}$ \\
\hline
\end{tabular}




\begin{tabular}{|c|c|c|}
\hline & $\begin{array}{l}\text { programming and } \\
\text { debugging. }\end{array}$ & \\
\hline 2017 & $\begin{array}{l}\text { Difference compared } \\
\text { with content of 2016: } \\
\text { Mechanical and } \\
\text { electrical installation and } \\
\text { debugging for single } \\
\text { suction and double } \\
\text { suction six-axis } \\
\text { industrial robot } \\
\text { end-effectors was } \\
\text { replaced by mechanical } \\
\text { and electrical installation } \\
\text { and debugging for air } \\
\text { claws and double suction } \\
\text { machines; recognition of } \\
\text { the shape type, position } \\
\text { and angle of joints of } \\
\text { simulation robots; coding } \\
\text { of the underlying control } \\
\text { program for palletizing } \\
\text { machines. }\end{array}$ & $\begin{array}{l}\text { 1.Technologies and skills: Compared with the } \\
\text { content of 2015, the following were added: Chain } \\
\text { transmission, belt transmission, gear transmission } \\
\text { and other typical mechanical transmission } \\
\text { technologies; industrial site network technology. } \\
\text { 2.Professional standards: Compared with the } \\
\text { standards of 2015, the following standards were } \\
\text { added: Industrial robot - Graphical user interface } \\
\text { for programming and operation of robots (GUI-R) } \\
\text { GB/T 19399-2003, Industrial robot - Intermediate } \\
\text { Code for Robot (ICR) GB/Z 20869-2007, General } \\
\text { specification of assembly robots (GBT } \\
\text { 26154-2010), Industrial robots - Safety } \\
\text { specification (GB 11291-1997). }\end{array}$ \\
\hline
\end{tabular}

Table 3 Introduction to Installation and Debugging of Electrical Control System

\begin{tabular}{|c|c|c|c|c|}
\hline Item & Year & Content & Technical Specifications & Task \\
\hline 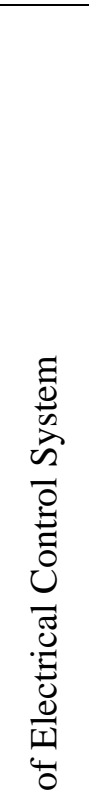 & 2015 & $\begin{array}{l}\text { The circuit } \\
\text { design, circuit } \\
\text { arrangement, } \\
\text { connection } \\
\text { process and } \\
\text { debugging of } \\
\text { modern } \\
\text { electrical } \\
\text { control systems; } \\
\text { complete the } \\
\text { PLC } \\
\text { programming, } \\
\text { touch screen } \\
\text { configuration, } \\
\text { network } \\
\text { communication } \\
\text { settings, and } \\
\text { driver parameter }\end{array}$ & $\begin{array}{l}\text { 1. Technologies and skills: electrical } \\
\text { technology, electrical measurement } \\
\text { technology, electrical control } \\
\text { technology, electrical engineering } \\
\text { drawing, motor drive and speed control, } \\
\text { programmable controller application } \\
\text { technology, touch screen configuration } \\
\text { control technology, industrial network } \\
\text { technology, sensor technology, etc. } \\
\text { 2. Occupational Standards: Code of } \\
\text { acceptance of construction quality of } \\
\text { electrical installation in building } \\
\text { construction (GB50303-2002), Code for } \\
\text { construction and acceptance of } \\
\text { low-voltage apparatus electric } \\
\text { equipment installation engineering } \\
\text { (GB50254-1996), Preparation of }\end{array}$ & $\begin{array}{l}\text { According to the control } \\
\text { requirements of the } \\
\text { three-dimensional warehouse } \\
\text { system, design the electrical } \\
\text { control schematic, complete the } \\
\text { components selection } \\
\text { calculation, installation, circuit } \\
\text { connection (including the main } \\
\text { circuit) and parameter settings } \\
\text { for related components, write } \\
\text { the PLC program and the touch } \\
\text { screen program, and debug the } \\
\text { system; troubleshoot the fault } \\
\text { set on the electrical control } \\
\text { circuit board of the X62W } \\
\text { milling machine, so that the } \\
\text { circuit can work normally to } \\
\text { complete the maintenance work. }\end{array}$ \\
\hline 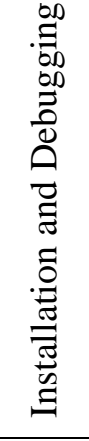 & 2017 & $\begin{array}{l}\text { settings } \\
\text { according to the } \\
\text { functional } \\
\text { requirements of } \\
\text { a given modern } \\
\text { electrical } \\
\text { control system; } \\
\text { enabling local } \\
\text { control unit } \\
\text { debugging and }\end{array}$ & $\begin{array}{l}\text { documents used in electrotechnology- } \\
\text { Part 3: Connection diagrams, tables and } \\
\text { lists (GB/T 6988-2008), Graphical } \\
\text { symbols for electrical diagrams } \\
\text { (GB/T4728-2005), Graphical symbols } \\
\text { for use on electrical equipment } \\
\text { (GB/T5465.2-1996), General rules for } \\
\text { the formulation of letter symbols in } \\
\text { electrotechnology (GB/T7159-1987). }\end{array}$ & $\begin{array}{l}\text { Different from the task of } 2015 \text { : } \\
\text { The controlling object of the } \\
\text { system was changed to the } \\
\text { fixed-length cutting system; the } \\
\text { troubleshooting object was } \\
\text { changed to the T68 boring } \\
\text { machine. }\end{array}$ \\
\hline
\end{tabular}




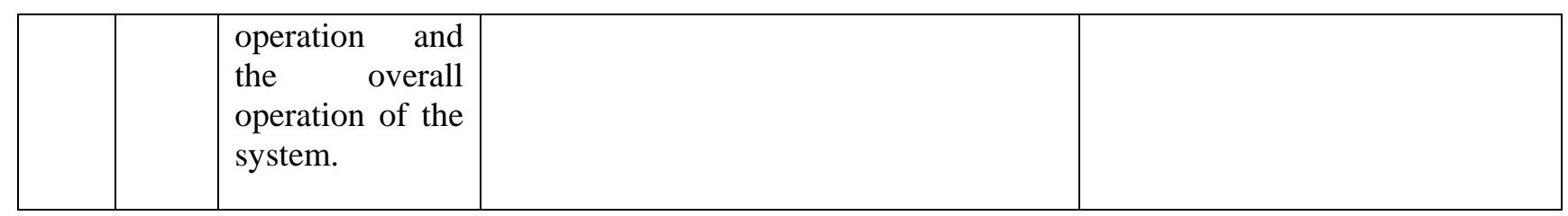

operation and

the overall

operation of the

system.

\begin{tabular}{|c|c|c|c|c|}
\hline \multirow{2}{*}{ Competition Item } & \multicolumn{2}{|c|}{ Provincial } & \multicolumn{2}{|c|}{ National } \\
\hline & Year & Prize & Year & Prize \\
\hline \multirow{4}{*}{$\begin{array}{c}\text { Installation and Debugging } \\
\text { of Automated Production } \\
\text { Lines }\end{array}$} & 2012 & Second Prize & 2012 & Second Prize \\
\hline & 2013 & Second Prize & 2013 & Third Prize \\
\hline & 2015 & First Prize & 2015 & Third Prize \\
\hline & 2017 & First Prize & & \\
\hline \multirow{2}{*}{$\begin{array}{c}\text { Application of Industrial } \\
\text { Robot Technology }\end{array}$} & 2016 & First Prize & 2016 & Second Prize \\
\hline & 2017 & First Prize & 2017 & Second Prize \\
\hline \multirow{2}{*}{$\begin{array}{l}\text { Installation and Debugging } \\
\text { of Electrical Control System }\end{array}$} & 2015 & First Prize & 2015 & Third Prize \\
\hline & 2016 & Second Prize & 2016 & Third Prize \\
\hline
\end{tabular}

\section{Consolidation of Professional Knowledge}

Students must grasp the professional basic knowledge of the specialty category for intelligent control technology and the extended knowledge of other related specialties during the preparation for the skills competition. Within the limited time of the skills competition, the students need to comprehensively apply these professional knowledges to interpreting the assignment, completing the competition tasks, and demonstrating their professional abilities in a timely manner. Although the technical platforms of the three competitions are not the same and the tasks are different, the technical elements involved regarding the specialties category for the intelligent control technology have common points, such as sensor technology, pneumatic technology, low-voltage electrical control technology, industrial network technology, programmable controller technology, frequency converter technology, stepper motor technology, electrical system installation and debugging technology, mechanical system installation and debugging technology, and system maintenance and fault detection technology. These technical elements are organically and comprehensively kneaded into the technology platform and the final task is to complete the installation and debugging of a flexible automated production line of a certain simulated industrial mission. In the competition for the application of industrial robot technology, the students were asked to leverage the mechanical adjustment knowledge to complete the assembly of the robot end effector and the upper conveyor belt of the AGV, leverage the sensor knowledge to adjust the sensitivity of the device, leverage pneumatic knowledge to complete the gas circuit connection, leverage the Siemens PLC1200 knowledge to write related controlling program and realize the multiple control (single-station, multi-station and whole line) of the palletizing machine, the vision system, the six-axis industrial robots and the assembly lines. At the end, the 3D warehouse, the AGV, the assembly line, the vision system and the six-axis industrial robots were integrated by the industrial network and the programmable control technology in completing the discharging from the warehouse, transiting, identification and sorting of gift boxes or simulating the robot base joints for discharging, transiting, identification, assembly and sorting.

During the four-and-a-half-hour's competition, to complete the entire line of operations required by the game mission, the students need to complete the mechanical installation, electrical connection, and pneumatic connection according to the process requirements, complete the program design, human-machine interface development, intelligent identification, and workpiece assembly according to functional requirements, and perform fault diagnosis and troubleshooting in response to field problems. In the class teaching, the teacher is more about guiding the students into the 
professional knowledge considering the overall progress of the whole class. Only the students who are hard at work and willing to study will gradually reach the depth and breadth of the knowledge required for the competition through reinforcement training. Only when the contestants have mastered these knowledge points and can apply these knowledges comprehensively will it be possible for them to complete the joint debugging of the production line, finish the industrial tasks and finally win the prize.

In the reinforcement training, the students often feel the lack of knowledge. As for the on-site competition experience, the contestants often summarize that "only when it comes to the application that you know the value of knowledge", and that there are still gaps to fill for them to meet the standards of artisans' talents. Therefore, they understand what is the direction for them in the mastering of professional knowledge. During our years of training on students for the competition of installation and debugging of automated production lines, a lot of the training students reported that they lacked the knowledge of pneumatic principles and that they connected the gas lines in the reversed way, that their knowledge of inverters was so negligible that the parameters were set incorrectly, and that the PLC knowledge learned from books was too theoretical and had not been used in practice, which caused the errors in the program logic so that the production line function did not meet the requirements of the assignment.

\section{Improvement of Practical Skills}

All professional masters start with knowledge, and learn through practice. The same process goes for the contestants for skills competition. With the premise of consolidating professional knowledge, proficient skills must be obtained from practice. The installation and debugging of both the automatic production lines and the electrical control systems involves the production of electronic wires , the design, installation and wiring of electrical control circuits, and the drawing of some circuit control schematics, wiring diagrams, and component tables. Through electrical control training, on the one hand, students' understanding of circuit structure, circuit composition, and circuit working principles can be further deepened, so that their practical skills in testing, modifying, and improving the circuit's independently will be cultivated, on the other hand, students' operations will conform to Code for construction and acceptance of low-voltage apparatus electric equipment installation engineering (GB50254-1996), Preparation of documents used in electrotechnology Part 3: Connection diagrams, tables and lists (GB/T 6988-2008), Graphical symbols for electrical diagrams (GB/T4728-2005), Graphical symbols for use on electrical equipment (GB/T5465.2-1996), General rules for the formulation of letter symbols in electrotechnology (GB/T7159-1987) and other technical standards. This can even improve the students' operation to meet the professional standards for electrical maintenance (National Vocational Qualification Level 3), and for programmable control system design (National Vocational Qualification Level 3). The competition of assembly and debugging of automated production lines requires the assembly of workstations. The competition of application of industrial robot technology involves the assembly of the robot end effector and the installation of the upper conveyor line of the AGV. The installation and adjustment of mechanical components on the one hand deepens the students' understanding of mechanical parts, mechanical assembly units and mechanical drawings, and on the other hand standardize the students' operation in accordance with National occupational standards for tool fitters (Occupation Code 6-05-02-02), National occupational standards for assembly fitters (Occupation Code 6-05-02-01), National occupational standards for mechanical equipment installers (Occupation Code 6-23-10-01) and equip them with the basic capabilities of fitters. Although only the competition of installation and debugging of the electrical control system lists the task of fault diagnosis and troubleshooting for the typical machine circuit, the other two competitions also involve troubleshooting based on the fault phenomenon, because the function implementation involves the programming and debugging of the control system. PLC programming cannot be accomplished with only one action. It requires continuous debugging based on the phenomenon. These tasks can effectively improve the student's operational ability and lay a solid foundation for students' ability to perform their jobs. 


\section{Improvement of Professionalism}

The three competition items will not only test the students' professional knowledge and practical skills, but also test the overall strength of the team in teamwork, planning, organizing, and communication. The competitions of the installation and debugging of automatic line, and the installation and debugging of electrical control system, test both the skills and the comprehensive quality of the students. The competition combines process evaluation, technique evaluation and function evaluation, which test both the students' capabilities in mechanical and electrical equipment installation and debugging, project implementation, team collaboration, planning and organizing, but also the students' professional quality, communication skills and awareness of efficiency, cost and safety.

First, foster professionalism. Foster the students' passion for the selected competition items so that they will devote themselves wholeheartedly to the entire competitions, study the rules of the game seriously and pragmatically, seek continuous improvement on their works, and maintain a high degree of enthusiasm and pragmatic hard work facing difficulties. Second, cultivate will and endurance. All the three competitions require the tasks of the competition to be completed within a short period of time to win a prize, which is a great challenge for the students both physically and psychologically. The students must concentrate all their efforts to complete the competition tasks, which is a demanding requirement on willpower and patience, pushing the students to constantly break through their limits. Third, develop the ability to analyze and solve problems. The three competitions are team competitions. Students should analyze the game assignments, interpret the content of the competition, figure out how to complete the assignment requirements with the concerted efforts of all the team members. While at the same time, each student must complete the task he/she is responsible for independently in the competition. The students should coordinate well before the work is presented. When problems or malfunctions occur, they must think actively and investigate and resolve them together. In this way, the ability of the students in analyzing and solving problems can be further enhanced.

\section{Conclusions}

Given the rules and standards of the competition items, the skills competitions strictly exam the proficiency of the students in professional knowledge and practical operations, their mastery of the students in the quality, craftsmanship and precision of works, and their ability to innovate their works. The skills competitions require the students not only to profoundly understand the technical rules and standards, and have full awareness of quality and precision, but also to emphasis on cultivating safety and environmental awareness and professional habits in workplace. Vocational students' skills competitions focus on the concept and methods of practical abilities training of skilled talents. With the development of the competitions, the competition items will be the real production projects. It shows that requirement of these competitions on talents training is to provide comprehensive talents who master the production standard requirements, advanced concepts, and technical standards and technologies.

\section{Acknowledgments}

This work was financially supported by A research project of the Education and Teaching Reform of Vocational Schools in Hunan Province in 2016 (JGB2016136).

Corresponding Author: Liu Chunyan.

\section{References}

[1] Y.C.Luo, M.J.Zhu, and D. Zheng, Investigation on enhancing talents cultivation quality by vocational skills competition in colleges, Vocational and Technical Education. 35 (752) 35-39.

[2] H.P.Wang, Z.S.Guo, and A.M.Wen. Practice and reflection on promoting professional 
connotation construction with skills competition: a case study, Jiangsu Education Research.35 (324) 35-37. 